\title{
ATTRIBUTION STYLES AS CORRELATES OF TECHNICAL DRAWING TASK-PERSISTENCE AND TECHNICAL COLLEGE STUDENTS' PERFORMANCE
}

\author{
Jane Itohan Oviawe ${ }^{1}$, Mohamed Nor Azhari Azman ${ }^{2 *}$, Tee Tze Kiong ${ }^{3}$, Oryngul S. Abilmazhinova ${ }^{4,5}$ \\ ${ }^{1}$ Ambrose Alli University, Nigeria \\ ${ }^{2}$ Universiti Pendidikan Sultan Idris, Malaysia \\ ${ }^{3}$ Universiti Tun Hussein Onn Malaysia, Malaysia \\ ${ }^{4}$ Kazakh Humanitarian Law Innovative University, Kazakhstan \\ ${ }^{5}$ Abai Kazakh National Pedagogical University, Kazakhstan \\ *e-mail: mnazhari@ftv.upsi.edu.my
}

\begin{abstract}
Technical drawing is a means of communicating between the designer and the manufacturers to bring ideas into reality by means of drafting. This study investigated attribution styles as collates of students' technical drawing task-persistence and academic performance using correlational research design. The population for this study consisted of 864 students of year II and the sample study comprised of 150 (93 males and 57 females) randomly selected from six technical colleges in Edo State, Nigeria. Three instruments, Academic Performance Attribution Style Questionnaire (APASQ), Technical Drawing Taskpersistent Rating Scale (TDTPRS); and Technical Drawing Performance Test (TDPT) were developed and used for data collection. Cronbach Alpha reliability method was used to determine the reliability of the instruments and the results were obtained: $\mathrm{SAASQ}=.87$; TDTPRS $=.79$; $\mathrm{AND}$ TDAT $=.85$. The findings of the study revealed that the technical drawing task-persistence of students was positively correlated by functional attribution style; and was negatively correlated by dysfunctional attribution style; functional attribution style positively correlated academic performance of students. Based on the findings of the study, it was recommended among others that technical drawing teachers should model and teach the students the right attribution style that will enhance their learning of technical drawing.
\end{abstract}

Keywords: attribution styles, academic performance, task-persistence.

\section{INTRODUCTION}

The possibility of all-round development as it is the demand of vision of the united Nation's 2030 sustainable development goals (SDGs) poses that all students develop through understanding of various subjects and skills that would enable students learn effectively in these fields. To accomplish this, adequate knowledge of technical drawing is required. This implies that in this technological age, knowledge of technical drawing is not only fundamental in the fields of science and technology but has become increasingly vital in all spheres of human life.

Technical drawing is the most popular, skill-oriented technical subject in any technical education programme be it at the Universities, Polytechnics, Colleges of Education (Technical), technical colleges or secondary schools (Oviawe \& Lukmon, 2017). It covers work done by architects, engineers, interior designers and electricians, technical drafters, craftsmen and technical teacher educators and students. Technical drawing is essentially the universal and graphic language of technology used by architects, technicians, engineers, technologists, designers, craftsmen, operators, manufacturers and industrialists to communicate ideas by means of pictures, drawings, graphics and symbols. It is a tool for communicating ideas between people on any object in industries, organizations, between countries, in the media - newspaper, magazines and television. Its objectives according to National Board for Technical Education (2008) are to use and care for the different drawing instruments, equipment and materials; understand and interpret the essentials of graphical communication; illustrate the construction of simple geometric figures and shapes; demonstrate the construction of isometric and oblique drawings and productions; understand the principles of orthographic projection; and explain the intersection of regular solid.

Technical drawing is a compulsory subject for all technology and engineering based subjects and programmes in technical colleges 
and tertiary institutions. It is the major mover of all other technically related subjects that forms a picture of concept of what should be drawn before actually drawing it. This has added more weight to the burden of any learner in Nigeria who is not well grounded in the knowledge of technical drawing; and this has made the effective teaching and learning an issue.

Nonetheless, in spite of the place of technical drawing in technological development and human endeavours, output in terms of academic performance has been increasingly poor among students. Student-factors in this context could be related to variables such as students' abilities, skills and orientations. Differences in learner's abilities put some learners in consistent low performance in technical drawing and other school subjects, hence low achieving students. Low achieving students are learners who have consistent low academic performance. Such students are of average or above average intelligent quotient (IQ), yet the experience difficulties in learning new materials, acquiring knowledge and skills to the normal level expected of those of the same age (Coleman \& Minnett, 1992).

There is an issue that has caused a pedagogical shift from teacher-centred learning to student-centred learning which is the hallmark of today's educational development. Woolfolk (2010) asserted that this has brought a turnaround in the field of education in general and educational research in particular; such that today, educational research has focused considerably on finding out how the student can learn well instead of how the teacher can teach well. In today's technological era, the focus of a professional teacher is how to make the student develop desirable learning skills to take full responsibility of their own learning. To achieve this, the teacher is thus faced with the issue of understanding and being equipped with the tools for diagnosing and managing the student-factor and learning materials in order to produce good students and provide good learning environment (Riyanto, Kuat, \& Tentama, 2020).

Higgins \& LaPointe (2012) stated that attribution is an individual's characteristic tendencies when inferring the cause of behaviours or events. Attributions refer to the way people explain causation (Heider, 1958; Weiner, 1986) and particularly, in this context, students' explanations of past academic failures. Some students tend to explain poor grades in terms of their own (internal) failings, such as lack of effort and ability. This is because, attributions may differ in their stability and globality. A pessimistic attribution style (Peterson, Vaillant, \& Seligman, 1988) is characterized by internal, stable (unchanging), and global (crosssituational) attributions for past failures (e.g., "I am stupid"). In contrast, optimistic students are likely to make external, unstable, and specific attributions for past failures (e.g., "The examiner did not understand my work"), and internal, stable, global attributions for past successes (e.g., "I am capable and smart. Each theory proposes that the attributions of learners have for their successes and failures can significantly affect their future performance of academic tasks.

Wang, Peng, Huang, Hou, \& Wang (2008) reported that students with controllable attributions for success and failure had higher reading scores and perceived academic selfefficacy compared to those with uncontrollable attributions. Attributions are the explanations that students give to explain causes of their academic failure or success. In the education context, Weiner (2005) proposed a theory that posits that the student's attributions for their successes or failures can significantly influence their performance in future. A strong relationship has also been established between causal attributions, students' future expectations and academic achievement (Bui, 2007; Khattab, 2015; Solar, 2015).

Task-persistence is the length of time and amount of effort a learner is able to apply in order to master a task or solve a problem or attain a goal (Higgins \& LaPointe, 2012). It is related to learning goals and motivation (Onatsu-Arvilommi \& Nurmi, 2000). Taskpersistence of low achieving students is vital because it is a learning skill that when applied can help the students overcome the issue of poor achievement. Similarly to other motivational constructs (Pintrich \& Schunk, 2002), task persistence as a part of learning behaviour is an important determinant of children's learning and acquisition of academic skills. Martin \& Omela (2020) said that, task-persistence is the tendency of a learner to stick to a task until it is completed. It can thus be seen as a behavioural process that is motivated over time 
in a continuing pursuit of an outcome, goal or a particular course of activities which necessarily involves a progression of distinct actions. High task-persistence is one of the characteristics of mastery-oriented learners who are not worried about their present performance, but focus on the mastery of task. Thus, to master the task, students need a quantum of persistence which in turn improves their learning outcome attainment.

Kallick \& Zmuda (2017) posited that learning outcomes are the knowledge, skills, attitudes and habits of mind that students take with them from a learning experience. According to Agus \& Samuri (2018), learning outcomes are those statements that specify what the learner will know or be able to do as a result of a learning activity; expressed as knowledge, skills or attitude. They focus on what the students will be able to do at the end of a given period of time and show how that knowledge or skill will be demonstrated. For example, upon completing this assignment, the learners should be able to provide an accurate diagram of a gear, identify and develop type of gear, prepare/produce a device that uses gear.

A unit of instruction, course assignment or workshop might have multiple learning outcomes which help to focus on students' behaviour that is to be changed; serve as guidelines for content instruction and evaluation; identify specifically what should be learned and convey to the students what exactly is to be accomplished. The success of any teaching activity can be measured by the level of achievement of learning outcomes; which can be assessed by diverse testing styles. Woolfolk (2010) asserted that students learning in the school context can see the learning outcomes as learning goals. Kiong et al. (2012) posited that learning outcomes of the lesson are presented to the learner as goals which can be used to direct attention; energize effort; promote the development of new knowledge and strategies; and increase persistence.

In a student-centred learning environment, learning outcomes/goals are made known to the students as it is in the curriculum, so that both the students and the teacher can work mutually in the direction of accomplishing them. The teacher subsequently measures the level of realization towards making necessary changes and reinforcements. Accomplishment of the learning outcomes explains the success of learning because of the sensitivity of the learning outcomes; this study investigates the extent to which learning outcomes can be correlated by attribution styles.

\section{METHOD}

The study adopted the correlational survey research design to investigate the relationship between students' attribution styles and their task-persistence and academic performance in technical drawing in Edo State technical colleges.

The population for the study consisted of all the 864 vocational II technical drawing students from the technical colleges in Edo State, Nigeria. The sample for comprised of 150 vocational II (93 males and 57 females) students selected through multi-stage sampling techniques, from six technical colleges in Edo State. Initially, the researcher stratified the technical colleges into the three senatorial districts. Out of the three senatorial districts, simple random sampling technique was used to select three technical colleges through balloting. This implied that a technical college was sampled from each senatorial district. They purposive sampling was employed to sample all the low achieving students in vocational II as identified through the technical college records continuous assessment.

The three instruments used for data collection were developed by the researcher from literature reviewed (Dykema, Bergbower, Doctors, \& Peterson, 1996; Constantine, Holman, \& Hojbota, 2011; DiCerbo, 2016; Ang, Masood, \& Abdullah, 2016). They are: Students Academic Attribution Style Questionnaire (SAASQ); Technical Drawing Task-persistence Rating Scale (TDTPRS); and Technical Drawing Achievement Test (TDAT). Cronbach Alpha reliability method was used to determine the reliability of the instruments and the results were obtained: SAASQ $=.87$; TDTPRS $=.79$; AND TDAT $=.85$. All three instruments were validated by three (3) experts. SAASQ consisted of 10 items meant to obtain information about the students' academic attribution styles with a seven point Likert scale of Strongly Agreed (7) to Strongly Disagree (1). Three experts in educational psychology and test and measurement face validated the instrument. To determine the reliability of SAASQ, it was trial 
tested on 20 students within the target population but who were not included in the study and data collected were analyzed using Cronbach Alpha method; a reliability coefficient of .87 was obtained.

TDTPRS consisted of 10-items and was completed by technical drawing teachers on each student to rate the extent to which students persists in carrying out technical drawing problems/tasks with a seven point Likert scale of Strongly Agreed - 7, Agreed - 6, Somewhat Agree - 5, Agreed nor Disagree - 4, Somewhat Disagree -3 , Disagreed - 2, and Strongly Disagree -1 . Three (3) experts in educational psychology and test and measurement face validated the instrument. The data collected from the trial testing was analyzed using Cronbach Alpha method; and reliability coefficient of .79 was obtained.

The development of TDAT was guided by a test blue-print which covers the five levels of Bloom's taxonomy of Educational objectives (Knowledge, comprehension, Application, Analysis, Synthesis and Evaluation). TDAT was face by three experts in technical education and test and measurement face validated the instrument. The internal consistency of TDAT was determined using Kuder Richardson $21\left(\mathrm{~K}_{\mathrm{R}}\right.$. $\left.{ }_{21}\right)$ formulae and a reliability coefficient of .85 was obtained. $\mathrm{K}_{\mathrm{R}-21}$ was considered appropriate for the instrument because TDAT was dichotomously scored, that is each item has one correct answer outside which the mark is lost.

Prior to the commencement of the study, the research with the assistance of two trained research assistance administered SAASQ to the students in order to determine students with different attribution styles. Upon completion of the instrument all the 150 copies of the questionnaires were collected and used for data analysis. Thereafter, TDAT was administered. Here, the students were required to show all their works in terms of steps followed in carrying out the technical drawing tasks/problems. The teacher, the researcher and the research assistants then rated and recorded the task-persistence of the students as they perform the tasks in the TDAT. The test did not have specific duration but students were told to submit as soon as they are through; or they cannot try further.
Data collected were analyzed using Mean and standard to answer the research questions and Pearson Product Moment correlation statistics.

\section{RESULTS AND DISCUSSION Results}

The Pearson Product Moment Correlation analysis on the relationship between functional attribution styles on technical drawing taskpersistence of low achieving students'. The analysis implies a high positive correlation between students' functional attribution styles and their technical drawing task-persistence with a calculated coefficient $(r)$ of .70 . This indicates that students' who had high scores in functional attribution style persisted highly in technical drawing tasks. There is no significant relationship between Functional Attribution style and the Technical Drawing task-persistence of low achieving students'.

The one-way ANOVA shows that functional attribution style significantly correlates technical drawing task-persistence of low achieving students'. This is seen in the $F$-value of 96.01 which is significant at .000 , which is also significant at .05 level of significant; and the t-calculated value of -9.79 which is also significant at .000 and .05 levels. Thus, the null hypothesis which states that there is no significant relationship between Functional Attribution style and the Technical Drawing task-persistence of low achieving students' is rejected. Hence, the alternate hypothesis which states that there is significant relationship between Functional Attribution style and the Technical Drawing task-persistence of low achieving students'.

The Pearson Product Moment Correlation analysis on the relationship between functional attribution styles on technical drawing academic performance of low achieving students' with a calculated $r$ of .67. This implies that students who had high scores in functional attribution styles had high academic performance of technical drawing tasks. Hypothesis 2 further addressed this research question.

The Pearson Product Moment Correlation analysis on the relationship between dysfunctional attribution styles on technical drawing task-persistence of low achieving 
students'. The analysis revealed a negative correlation between students' dysfunctional attribution styles and their technical drawing task-persistence with a calculated coefficient $(r)$ of -.55. This indicates that students' who had low scores in dysfunctional attribution style had low mean technical drawing academic performance score. Hypothesis 3 further addressed this research question.

The Pearson Product Moment shows a negative correlation between dysfunctional attribution styles and technical drawing performance score of low achieving students' with calculated $r$ of .-16. This implies that students' who had dysfunctional attribution style had low mean technical drawing performance score. Dysfunctional attribution style does not significantly correlate technical drawing performance of low achieving students'. The three correlations can be seen in Figure 1 .

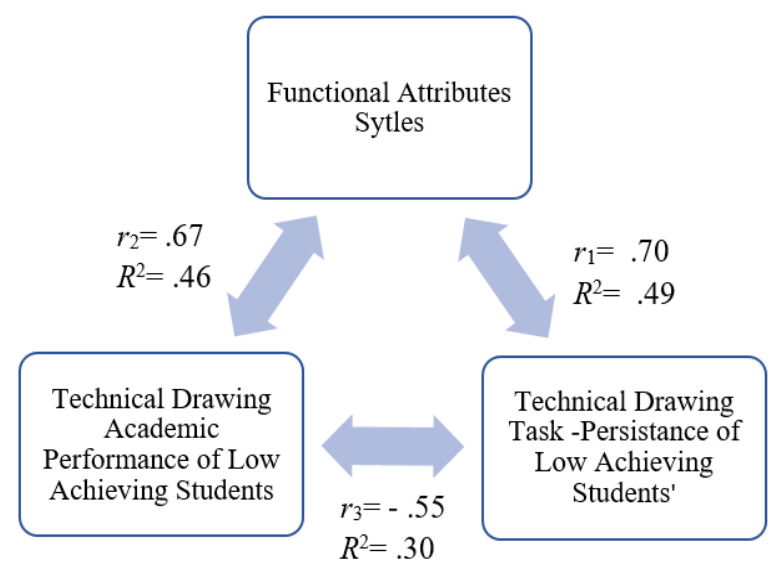

Figure 1. The Correlation Model

\section{Discussion}

The findings of the study revealed that there is a positive correlation between functional attribution style and technical drawing taskpersistence of low achieving students; and functional attribution style correlates students' technical drawing task-persistence. This implies that functional attribution results in high taskpersistence as such attribution style gives students more success expectancies, hopefulness and behavioural persistence during academic task. The findings of the study also revealed that dysfunctional attribution style has a high negative correlation with; and negatively correlates the task-persistence of lowing achieving students. This means that the higher dysfunctional attribution style, the lower the task-persistence.
This could be as a result that dysfunctional attribution style brings about low expectancy of future success and feelings of hopelessness and thus result to low persistence in task; opposite is the case of functional attribution style.

This finding is in line with that of Higgins \& LaPointe (2012) who reported that functional attribution style resulted to increased persistence while dysfunctional attribution style resulted in low persistence. They also said that, taskpersistence of low achieving students is vital because it is a learning skill that when applied can help the students overcome the issue of poor achievement. Task-persistence is the length of time and amount of effort a learner is able to apply in order to master a task or solve a problem or attain a goal.

Similarly, Martin \& Omela (2020) reported that attribution style did predict taskpersistence to corroborate the findings of this study. This could be so because if an individual had the orientation that enables him/her assume or believe that failure or success in academic performance in all aspects of life (technical drawing inclusive) depend completely on self and the totality of attempt made, the person is likely to persist more at tasks of importance to $\mathrm{him} / \mathrm{her}$, than a person who sees efforts as useless and always believe in external variables such as luck and task-difficulties as determinants of success or failures. This means that when students fail, they are most likely to persist and eventually succeed only if they attribute their failure to a lack of appropriate effort. Besides, task-persistence is the tendency of a learner to stick to a task until it is completed. It can thus be seen as a behavioural process that is motivated over time in a continuing pursuit of an outcome, goal or a particular course of activities which necessarily involves a progression of distinct actions.

Curiosity, interest, emotions and motivation (which can be based on previous success or failure) influence the task-persistence of the student Martin \& Omela (2020). In addition, the type of goal and goal orientation of a person has determines his/her task-persistence (Woolfolk, 2010). High task-persistence also is one of the characteristics of mastery-oriented learners who are not worried about their present performance, but focus on the mastery of task. Howard-Rose \& Winne (1993) asserted 
that another factor that explains the learner's persistence is the type of lesson scenario a child is exposed to; hence it was noted that for students to succeed in technical drawing, there is need to strike a balance between: task that has sufficient opportunities for success and that which requires considerable effort. Thus, to master the task, students need a quantum of persistence which in turn improves their learning outcome attainment. The findings of the study also suggest that it is not beneficial for students to attribute their successes entirely to ability. If they believe they already have all the ability they require, they may feel that additional effort is superfluous. The ideal attribution for success is 'I succeeded because I am a competent person and worked hard'.

From the ideal attribution for that success, student-factors may include those specific characteristics (some of which may be negative or maladaptive) that constitute the learner as an entity; which can collectively or separately affect the learners' learning (Wang et al., 2008). These characteristics which may affect learning include learners' attribution styles, among others. Higgins \& LaPointe (2012) stated that attribution is an individual's characteristic tendencies when inferring the cause of behaviours or events. Attributions are the causal explanations that people assign to the events that happen to and around them. Persons tend to create diverse inferences about the cause of their successes or failures, hence attribution styles. Higgins \& LaPointe (2012) posited that attribution styles are the different dimensions which individuals tend to infer or explain the causes of events or outcomes. If referring from educational context, the two influential theories of attribution are Abramson, Seligman, \& Teasdale's (1978) theory of learned helplessness and Weiner's (1986) theory of motivation.

Each of these theories describes three slightly different dimensions along which particular attributions can be measured. For the theory of learned helplessness these three dimensions are stability, locus of control and globally, while for the theory of motivation, they are stability, locus of causality and controllability. Four factors are related to these dimensions of attribution theory that influence motivation in education: ability, task difficulty, effort, and luck. In terms of the characteristics earlier addressed, these four factors can be analyzed in the following way: Ability is a relatively internal and stable factor over which the student does not exercise much direct control. Task difficulty is an external and stable fact that is largely beyond the student's control. Effort is an internal and unstable factor over which the student can exercise a great deal of control. Luck is an external and unstable factor over which the student exercises very little control.

From Pierce \& Henry (1993) study, on attributional style as a predictor if success in college mathematics reported that both specific attribution and causal dimensions are equally effective in predicting grades. Similarly, Matthews \& Moran (2011) found that the attribution students made to failure significantly correlated with grade point average. These studies were conducted in Europe and other Western nations and need to be confirmed with students in Nigeria with different socioeconomic background. Thus, it is likely given the relationship between persistence and a person's task performance, that students who attribute their failures to insufficient effort (that is those that have functional attribution style) are more likely to exhibit high task-persistence. Hence, the alternate hypothesis which states that there is significant relationship between Functional Attribution style and the Technical Drawing task-persistence of low achieving students'.

The findings of the study also revealed that there is high positive functional attribution style and technical drawing academic performance of low achieving students; and that functional attribution style significantly correlates their academic performance in technical drawing. Similarly, the findings revealed a high negative correlation between dysfunctional attribution style; and that dysfunctional attribution styles negatively correlates technical drawing academic performance of low achieving students. This implies that academic performance increases with functional academic attribution and decreases with dysfunctional academic attribution of low achieving learners. The findings of this study is in line with those of Higgins \& LaPointe (2012); Pierce \& Henry (1993) who reported that attribution style is what made students to success and failure significantly correlated with their grade point average.

The findings could be given details by the 
fact that learners with functional attribution style are more like to try harder and persist on technical drawing task until positive learning outcomes are achieved than those with dysfunctional attribution style. Nonetheless, in spite of the place of technical drawing in technological development and human endeavours, output in terms of academic performance has been increasingly poor among students. This is evident in the analysis of students' results in NABTEB according to Chief Examiners' report of the National Business and Technical Examination Board from 2009 to 2013 revealed that the percentage of failure is higher than the percentage of credit pass annually. This depicts an ugly trend in the students' performance in NABTEB technical drawing. Also, the National Board for Technical Education in the year 2009, 2010, 2011 and 2012 asserted that the overall achievement of students in technical drawing has been quite low with the highest mean score in technical drawing recorded as $34.67 \%, 38 \%$, $40.43 \%$ and $27.78 \%$ respectively.

Research has revealed that factors that surround effective learning of school subjects (technical drawing inclusive) include student factor, teacher factor, the curriculum and the factor relating to availability of learning facilities (Okoye \& Edokpolor, 2021; Shaari, Yamin, \& Ahmad, 2021). Student-factors in this context could be related to variables such as students' abilities, skills and orientations.

Differences in learner's abilities put some learners in consistent low performance in technical drawing and other school subjects, hence low achieving students. Low achieving students are learners who have consistent low academic performance. Such students are of average or above average intelligent quotient (IQ), yet the experience difficulties in learning new materials, acquiring knowledge and skills to the normal level expected of those of the same age (Coleman \& Minnett, 1992). Such could contribute to the difference in academic performance among students with the same experience and condition. In that case, while the average learners and high achieving learners will be scoring $50-69 \%$ and $70 \%$ and above, the low achieving learners perform below average of $40 \%$ indicating that they perform below the average expected performance. Due to the consistent low academic performance of low ability students, they tend to develop maladaptive attribution patterns which can inhibit their improvement; make them to lack the relevant academic and technical skills that would enable them perform better in future such as task-persistence. Kiong et al. (2012) posited that consequently, the students could be kept in continued cycle of poor attainment of learning outcomes irrespective of teachers' efforts to help such students.

Besides, Higgins \& LaPointe (2012) asserted that during repeated failures in an academic task, the performance success, hopefulness and behavioural persistence of students with a dysfunctional attribution style were lower than those of students with a functional attribution style. Each theory proposes that the attributions of learners have for their successes and failures can significantly affect their future performance of academic tasks. For example, if a learner holds a belief that they do not have the capability to achieve in a task, and this belief is continually reinforced by frequent failures; then it is to be expected that the learners will reduce the amount of effort they expend to achieve the task.

Furthermore, if a learner concludes that their ability is the main reason limiting their progress in reading; it is likely that they will disengage when reading is the area of study (McLeod, 2010). In addition, Wang et al. (2008) reported that students with controllable attributions for success and failure had higher reading scores and perceived academic selfefficacy compared to those with uncontrollable attributions: hence, holding the belief that someone's control over the learning outcomes in an integral aspect of task motivation and perseverance. In addition, the study observed that internal attributions (ability and effort), for success and failure, were associated with academic progress. Hence, the alternate hypothesis which states that there is significant relationship between Functional Attribution style and the Technical Drawing academic performance of low achieving students'.

Generally, it is best for learners to believe that it is their behaviour rather than external circumstances that leads to success or failure. For example, it is good for students to have a realistic understanding of what leads to their academic success or failures. Invariably, Fadilla, Abdullah, \& Wu (2020) identified two types of attribution 
styles: adaptive and maladaptive attribution style. Also, Higgins \& LaPointe (2012) identified two major attribution styles for academic success and failure: functional academic attribution style and dysfunctional academic attribution style. Functional academic attribution styles involve attributing failures to internal-controllableunstable factors such as effort: which gives the student more success expectancies, hopefulness and behavioural persistence during academic task. While dysfunctional academic attribution style involves attributing failures to internaluncontrollable-stable factors such as low ability has led to low expectancy of future success and feelings of hopelessness and low persistence in task (Higgins \& LaPointe, 2012).

Reveal that the most successful learners have a tendency to overestimate the degree to which their own behaviour leads to success or failure that is, functional attribution style. Thus, learners tend to put more effort when they are confronted with failure or poor academic performance. Nevertheless, when students have the assurance that they lack ability due to their persistent poor academic performance, such students are likely to repudiate successes. For instance, when students do well, they are likely to have a sincere conviction that they were 'just lucky'. Such conviction would inhibit their subsequent effort and persistence and eventually hampers their progress in realization of academic performances.

\section{CONCLUSION}

It is concluded that students with functional attribution style persist significantly better that those with dysfunctional attribution style in technical drawing tasks; students with functional attribution style had higher technical drawing academic performance than those with dysfunctional attribution style; attribution styles significantly correlates technical drawing task-persistence of students. Attribution styles significantly correlate students'technical drawing academic performance. Based on the findings of this study, the following recommendations were made.

Technical drawing teachers should model and teach learners the right attribution styles that will help them in learning; when learners reject the value of effort, it is important to change their perception. This can be done by clarifying the meaning of effort and by seeing to it that effort does actually pay off. Also, if learners attribute their success to luck, it may be best to refrain from arguing with their attributions, but simply praise or otherwise reinforce them for their effective use of academic learning time.

Students should be guided towards developing functional attribution style in order to persist and succeed in technical drawing tasks. Technical teachers should help the learners to achievable learning goals which individual student will seek to increase their competence. Individuals who emphasize learning goals are likely to seek challenges, if they believe the challenges will lead to greater competence; and they tend to respond to failure by increasing their effort.

Lastly, technical drawing in the studio or classroom should be planned in such a way that effort will always lead to success. This is to avoid the low achieving learners developing learned helplessness - the expectation, based on previous experiences that a person's actions cannot possibly lead to success. This is because if the students' effort today is reinforced by success, he/she is likely to persist subsequently in such situations.

\section{REFERENCES}

Agus, R., \& Samuri, S. M. (2018). Learning analytics contribution in education and child development: A review on learning analytics. Asian Journal of Assessment in Teaching and Learning, 8, 36-47. https:// doi.org/10.37134/ajatel.vol8.4.2018.

Abramson, L., Seligman, M., \& Teasdale, J. (1978). Learned helplessness in humans: Critique and reformulation. Journal of Abnormal Psychology, 87(1), 47-74. https://doi.org/10.1037/0021$\underline{843 X} .87 .1 .49$.

Ang, L. W., Masood, M. C., \& Abdullah, S. H. (2016). Analysing the relationship of sequential and global learning styles on students' historical thinking and understanding: A case study on form four secondary schools students in Malaysia. Asian Journal of Assessment in Teaching and Learning, 6, 51-58. https://ejournal. upsi.edu.my/index.php/AJATeL/article/ view/1978. 
Bui, K. (2007). Educational expectations and academic achievement among middle to high school students. Education, 127(3), 328-331. https://go.gale.com/ps/i.do?id= GALE\%7CA205494746\&sid=googleSch olar\&v $=2.1 \& i t=r \&$ linkaccess $=a b s \& i s s n=$ $00131172 \& \mathrm{p}=\mathrm{AONE} \& \mathrm{sw}=\mathrm{w} \&$ userGrou $\mathrm{pName}=$ anon $\% 7 \mathrm{Ea} 76 \mathrm{~b} 62 \mathrm{c} 4$.

Coleman, J.M., \& Minnett,A. M.(1992).Learning disabilities and social competence: A social ecological perspective. Exceptional Children, 59(3), 234-246. https://doi. org/10.1177/001440299305900307.

Constantine, T., Holman, A., \& Hojbota, A. M. (2011). Developmental and validation of a motivational persistence scale. Psihologija, 45(2), 99-120. https://doi. org/10.2298/PSI1202099C.

DiCerbo, K. E. (2016). Assessment of task persistence. Y. Rosen, S. Ferrara, \& M. Mosharraf (Eds.) Handbook of research on technology tools for real-world skill development. Hershey, PA: IGI Global, pp. 778-804. https://doi.org/ 10.4018/978-14666-9441-5.ch030.

Dykema, J., Bergbower, K., Doctors, J. D., \& Peterson, C. (1996). An attributional style questionnaire for general use. Journal of Psychoeducational Assessment, 14(2), 100-108. https://doi. org/10.1177/073428299601400201.

Fadilla, P. F., Abdullah, S. M., \& Wu, M. (2020). Does conformity occur during students' decision making for their careers? Asian Journal of Assessment in Teaching and Learning, 10(1), 1-9. https://ejournal. upsi.edu.my/index.php/AJATeL/article/ view/3287.

Heider, F. (1958). The psychology of interpersonal relations. New York, NY: John Wiley \& Sons.

Higgins, N. C., \& LaPointe, M. R. P. (2012). An individual differences measure of attributions that affect achievement behaviour: Factor structure and predictive validity of the academic attributional style questionnaire. SAGE Open, 2(4), 1-15. https://doi. org/10.1177/2158244012470110.

Howard-Rose, D., \& Winne, P. H. (1993). Measuring components and sets of cognitive process in self-regulated learning. Journal of Educational Psychology, 85(4), 591-604. https://doi. org/10.1037/0022-0663.85.4.591.

Kallick, B., \& Zmuda, A. (2017). Students at the center: Personalized learning with habits of mind. Alexandria, Virginia: ASCD.

Khattab, N. (2015). Students' aspirations, expectations and school achievement: What really matters? British Educational Research Journal, 41(5), 731-748. https:// doi.org/10.1002/berj.3171.

Kiong, T. T., Yunos, J. B. M., Hassan, R. B., Heong, Y. M., Mohamad, M. M. B., Hussein, A. B. H., ... \& Othman, W. B. (2012). An evaluation of the Buzan mind mapping module as a guide for teachers on note-taking technique. Asian Journal of Assessment in Teaching and Learning, 2, 60-74. https://ejournal.upsi.edu.my/ index.php/AJATeL/article/view/1925.

Martin, M. D. M., \& Omela, M. C. (2020). Performance task as instrument for evaluation among grade VI pupils in public elementary schools. Asian Journal of Assessment in Teaching and Learning, 10(1), 40-49. https://ejournal.upsi.edu. my/index.php/AJATeL/article/view/3477.

Matthews, J. \& Moran, A. (2011). Physical activity and self-regulation strategy use in adolescents. American Journal of Health Behaviour, 35(6), 807-814. https://doi. org/10.5993/ajhb.35.6.16.

McLeod, S. (2010). Attribution theory. http:// www.simplypsychology.org/attributiontheory.html.

National Board for Technical Education. (2008). Curriculum for technical colleges. Kaduna, Nigeria: NBTE Press. 
Okoye, K. R., \& Edokpolor, J. E. (2021). Effect of industrial work experience in developing technical and vocational education undergraduates' employability skills. Asian Journal of Assessment in Teaching and Learning, 11(1), 1-12. https://ejournal.upsi.edu.my/index.php/ AJATeL/article/view/4789.

Onatsu-Arvilommi, T., \& Nurmi, J.-E. (2000). The role of task-avoidant and taskfocused behaviors in the development of reading and mathematical skills during the first school year: A cross-lagged longitudinal study. Journal of Educational Psychology, 92(3), 478-491. https://doi. org/10.1037/0022-0663.92.3.478.

Oviawe, J. I., \& Lukmon, A. (2017). Effects of concept mapping instructional strategy on students' academic performance and interest in technical drawing in technical colleges in Edo State, Nigeria. IOSR Journal of Research and Method in Education (IOSR-JRME), 7(3), 9-15. $\quad$ https://doi.org/10.9790/7388$\underline{0703030915 .}$.

Peterson, C., Seligman, M. E., \& Vaillant, G. E. (1988). Pessimistic explanatory style is a risk factor for physical illness: A thirtyfive-year longitudinal study. Journal of Personality and Social Psychology, 55(1), 23-27. https://doi.org/10.1037/00223514.55.1.23.

Pierce, M.A., \& Henry, J. W. (1993). Attributional style as a predictor of success in college mathematics. Education Resources Information Center, 1-27. https://files. eric.ed.gov/fulltext/ED365528.pdf.

Pintrich, P. R., \& Schunk, D. H. (2002). Motivation in education. Englewood Cliffs, NJ: Prentice Hall.

Riyanto, J., Kuat, T., \& Tentama, F. (2020). The influence of work competence, learning motivation, independence and discipline on work readiness of vocational school students in Cilacap regency. Asian Journal of Vocational Education and Humanities, 1(2), 39-57. https://www.arsvot.org/ index.php/ajvah/article/view/7.

Shaari, J., Yamin, S. I. A., \& Ahmad, M. I. (2021). Impak penggunaan aplikasi terhadap proses pengajaran dan pembelajaran pelajar politeknik dalam kursus electrical technology. [The impact of the use of applications on the teaching and learning process of polytechnic students in electrical technology courses]. ANP Journal of Social Science and Humanities, 2(2), 30-34. https://arsvot.org/index.php/ anp-jssh/article/view/46.

Solar, N. J. B. (2015). Attribution of academic performance among third year and fourth year biology major students. Journal of Psychology and Psychotherapy, 5(5), 1-6. $\quad$ https://doi.org/10.4172/2161$\underline{0487.1000210 .}$.

Wang, Y., Peng, H., Huang, R., Hou, Y., \& Wang, J. (2008). Characteristics of distance learners; Research on relationships of learning motivation, learning strategy, selfefficacy, attribution and learning results. Open learning, 23(1), 17-28. https://doi. org/10.1080/02680510701815277.

Weiner, B. (1986). An attributional theory of achievement, motivation and emotion. In B. Weiner (Ed.). An attributional theory of motivation and emotion. New York, NY: Spinger, pp. 159-190. https://doi. org/10.1007/978-1-4612-4948-1_6.

Weiner, B. (2005). Motivation from an attribution perspective and the social psychology of perceived competence. In A. J. Elliot \& C. S. Dweck (Eds.). Handbook of competence and motivation. New York, NY: Guilford Press, pp. 73-84.

Woolfolk, A. E. (2010). Educational psychology $\left(11^{\text {th }}\right.$ ed). Upper Saddle River, NJ: Pearson. 